Endri Martini, Ummu Saad,Yeni Angreiny, James M. Roshetko, Hendra Gunawan, Heru T. Maulana, Gusti Suganda, Gusti Dwipayana, La Ode M. Erwin, Abdul Hadedi 

Agroforestry and Forestry in Sulawesi series:

Evaluation of the

Agroforestry Farmer Field Schools on Agroforestry Management in South and Southeast Sulawesi, Indonesia

Endri Martini, Ummu Saad, Yeni Angreiny, James M. Roshetko, Hendra Gunawan, Heru T. Maulana, Gusti Suganda, Gusti Dwipayana, La Ode M Erwin, Abdul Hadedi 


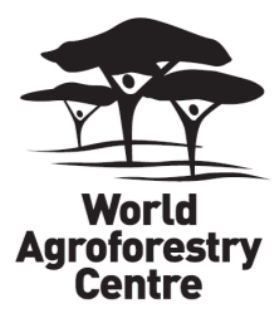

\section{Correct citation}

Martini E, Saad U, Angreiny Y, Roshetko JM, Gunawan H, Maulana HT, Suganda G, Dwipayana G, Erwin LO, Hadedi A. 2016. Agroforestry and Forestry in Sulawesi series: Evaluation of the Agroforestry Farmer Field Schools on agroforestry management in South and Southeast Sulawesi, Indonesia. Working paper 220. Bogor, Indonesia: World Agroforestry Centre (ICRAF) Southeast Asia Regional Program. 16p. DOI: 10.5716/WP16002.PDF.

Titles in the Working Paper series disseminate interim results on agroforestry research and practices to stimulate feedback from the scientific community. Other publication series from the World Agroforestry Centre include agroforestry perspectives, technical manuals and occasional papers.

Published by the World Agroforestry Centre (ICRAF)

Southeast Asia Regional Program

PO Box 161, Bogor 16001

Indonesia

Tel: +62 2518625415

Fax: +62 2518625416

Email: icraf-indonesia@cgiar.org

Website: http://worldagroforestry.org/regions/southeast_asia

(C) World Agroforestry Centre 2016

Working Paper 220

\section{Photos:}

The views expressed in this publication are those of the author(s) and not necessarily those of the World Agroforestry Centre.

Articles appearing in this publication may be quoted or reproduced without charge, provided the source is acknowledged.

All images remain the sole property of their source and may not be used for any purpose without written permission of the source. 


\section{About the authors}

Endri Martini is currently working at ICRAF as Agroforestry Extension Specialist since 2011. Previously she worked at ICRAF on various issues of agroforestry related to biodiversity conservation and community development. She obtained her master of science degree in natural resources and environmental management from University of Hawaii at Manoa, USA. Her bachelor degree was from Institute Pertanian Bogor, Forestry Faculty, majoring Silviculture.

Ummu Saad is currently working at ICRAF as Research Assistant for Agroforestry Extension Monitoring since 2013. She obtained her bachelor degree in Department of Socio Economic, Faculty of Animal Husbandry from Hasanuddin University, Makassar, South Sulawesi.

Yeni Angreiny is currently at ICRAF as Research Assistant For agroforestry Extension monitoring since 2013. She obtained her bachelor degree from Department of Socio Economic, Faculty of Agriculture, Halu Oleo University, Kendari, Southeast Sulawesi.

James M Roshetko is an Agroforestry Systems Scientist with the World Agroforestry Centre (ICRAF). He is the Leader of ICRAF's Southeast Asia Trees and Market Unit with 35 years of experience, including 18 years in Indonesia and 27 years in South and Southeast Asia. Jim is the Senior Team Leader of the CIDA-funded Agroforestry and Forestry in Sulawesi: linking knowledge to action project. His research interests focus on smallholder tree-based systems as viable agricultural and natural resources management systems that contribute significantly to local livelihood objectives and global environmental goals. He has a $\mathrm{PhD}$ in Geosciences and Natural Resource Management from the University of Copenhagen and a MSc in Forest and Agroforestry Management from Michigan State University.

Hendra Gunawan is currently working at ICRAF as Agroforestry Specialist since August 2013. He obtained his bachelor degree from Department of Forest Management, Faculty of Forestry, from Winaya Mukti University, Bandung, West Java.

Heru Tuwuh Maulana is currently working at ICRAF as Research Assistant since May 2014. He obtained his bachelor degree in 2011 from Department of Forest Management, Faculty of Agriculture, Haluoleo University, Southeast Sulawesi.

Gusti Suganda is currently working at OWT as Project Manager for TFCA project related to forest conservation and community development in East Kalimantan since 2014. Previously (2011-2014) he worked as Site Coordinator for AgFor project in East Kolaka and South Konawe. He obtained his bachelor degree from University of Halu Oleo, Faculty of Technic, majoring Architecture, Kendari, Southeast Sulawesi. 
Gusti Made Agus Dwipayana is currently working at OWT as Farmer Specialist for AgFor project in East Kolaka and South Konawe District since 2012. Previously he worked at OWT related to environmental conservation, community empowerment and the development of appropriate agricultural technology. He finished his highschool at SMA 1 Ladongi, Kolaka Timur, Southeast Sulawesi in 2007, and now he is pursuing his bachelor degree at Universitas Terbuka, Kolaka Timur, Southeast Sulawesi.

La Ode M Erwin is currently working at OWT as Farmer Specialist for AgFor project in East Kolaka and South Konawe District since 2013. Previously he worked at OWT related to environmental conservation, community empowerment and the development of appropriate agricultural technology. He obtained his bachelor degree from University of Haluoleo, Faculty of Mathematics and Natural Sciences, majoring Chemistry, Kendari, Southeast Sulawesi.

Abdul Hadedi is currently working at OWT as Governance Specialist for TFCA project related to forest conservation and community development in East Kalimantan since 2014. Previously (2012-2014) he worked as Farmer Specialist for AgFor project in East Kolaka and South Konawe. He obtained his bachelor degree from University of Halu Oleo, Faculty of Teacher Training and Education Science, majoring in English, Kendari, Southeast Sulawesi. 


\section{Abstract}

The Agroforestry Farmer Field School (AFFS) is a program implemented through the Agroforestry and Forestry: Linking Knowledge to Action (AgFor) project that seeks to improve the agroforestry garden management capacity of smallholder farmers in several provinces of Sulawesi Island, Indonesia. In principle, the method implemented in AFFS follows the participatory concept of farmer field schools, with the AFFS design based on the local context of AgFor sites in South and Southeast Sulawesi provinces. The AFFS was implemented from April 2013 to March 2014, with a focus on five main commodities prioritized by farmer partners, that is, pepper, clove, coffee, cacao and durian. Experts and scientists from Indonesian national research institutes were engaged as resource persons in the AFFS. One year after the program initiation, an evaluation was conducted through interviews of randomly-selected AFFS participants from four districts in South and Southeast Sulawesi provinces. The evaluation was conducted from April to July 2014 with 263 respondents (12\% of total AFFS participants). Results of the evaluation showed that $97 \%$ of the respondents gained benefit from attending AFFS. New and reliable knowledge or information was perceived as the most important aspect motivating farmers to attend AFFS. Results showed that one year after first implementation of AFFS, $14 \%$ of respondents had generated cash benefits from testing new knowledge learned during AFFS. The amount of money generated depended on the type of knowledge tested. Fertilizing and pruning were important techniques that yielded cash benefits for farmers in the short term (within one year). The evaluation concluded that after AFFS activities end, a minimum of one year of facilitation would be required to assist participants to effectively test and adapt the new knowledge learned.

\section{Keywords}

Agroforestry Farmer Field School, evaluation, coffee, durian, cacao, pepper, clove 


\section{Acknowledgements}

This study was implemented through the Agroforestry and Forestry: Linking Knowledge to Action (AgFor) project funded by the Department of Foreign Affairs, Trade and Development (DFATD), Government of Canada (Contribution Arrangement No. 7056890) and the CGIAR Research Program on Forests, Trees and Agroforestry. Additional assistance and contribution was provided by the collaborating communities and local government offices in Bantaeng, Bulukumba, Konawe and East Kolaka. The authors greatly appreciate that support, assistance and contributions. The authors also greatly appreciate the English editing made by Robert F. Finlayson. 


\section{Contents}

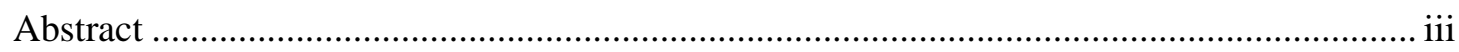

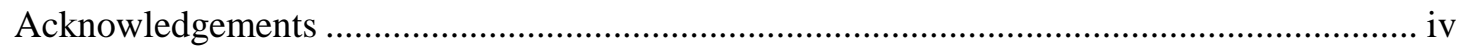

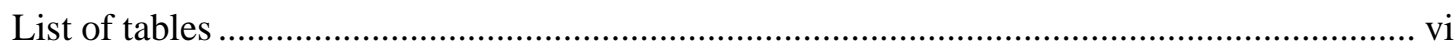

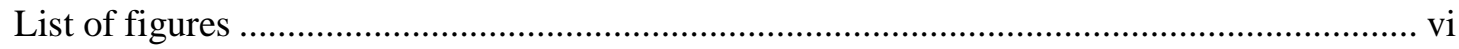

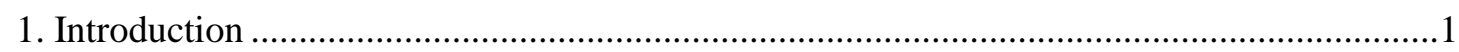

2. Agroforestry farmer field school concepts and framework in the AgFor Project ..................1

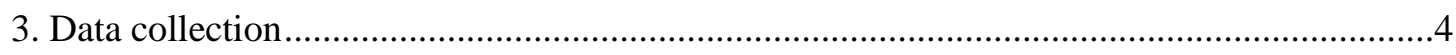

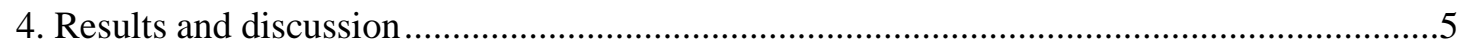

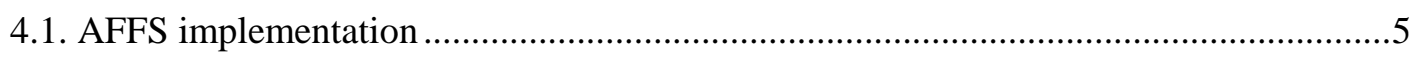

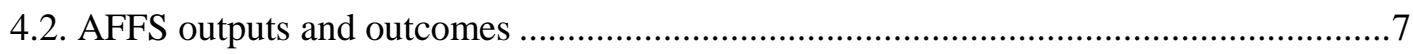

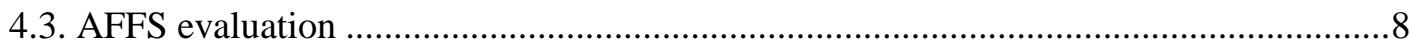

4.3.1. Topics and extension methods attended and preferred by respondents .................... 8

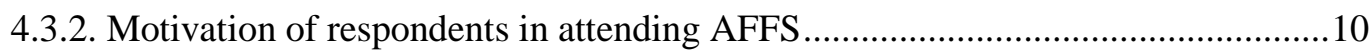

4.3.3. Benefits of AFFS based on respondents' perspectives ........................................11

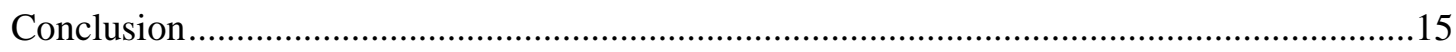

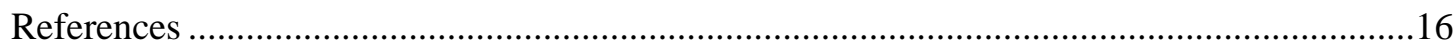




\section{List of tables}

Table 1. Technical committee for implementing AFFS

Table 2. Steps in each of AFFS 3 monthly-session

Table 3. Resource persons for each commodity in the AFFS

Table 4. AFFS events conducted from April 2013 to March 2014

Table 5. Improvement in yields from introduced new technology in AFFS based on farmers perspectives

\section{List of figures}

Figure 1. Concept of AgFor's Agroforestry Farmer Field Schools for Garden Management

Figure 2. Commodities proposed by farmers for inclusion in the AFFS in South Sulawesi and Southeast Sulawesi.

Figure 3. Topic of AFFS by commodities attended by respondents per province per gender

Figure 4. Extension method of AFFS attended by respondents per province per gender

Figure 5. Motivation of AFFS participants in attending per province per gender

Figure 6. Type of new knowledge obtained by AFFS participants per province per gender

Figure 7. Amount of money received from improvements made by respondents in their gardens with the information and knowledge they received from the AFFS 


\section{Introduction}

Farmers' management of their agroforestry gardens is very diverse. Owing to the nature of perennial crops, impact resulting from specific management may not be known for a year or more. Thus, any extension approach targeting garden management should focus on enhancing farmers' analytical skills and enriching their sources of information, which are essential for helping to decide the best-fit management options that will improve their gardens' productivity.

Farmer field schools can be an effective extension approach to enhance farmers' capacity in managing their gardens for higher and sustainable productivity. Hence, designing an Agroforestry Farmer Field School (AFFS) focused on tree-garden management would be expected to enhance agroforestry productivity, particularly, in areas where agroforestry systems have become the main source of livelihoods, as in Sulawesi, Indonesia.

In Sulawesi Island, Indonesia, a project focusing on agroforestry and forestry management for enhancing local livelihoods, called Agroforestry and Forestry: Linking Knowledge to Action (AgFor), which is funded by the Department of Foreign Affairs, Trade and Development (DFATD), Government of Canada and the CGIAR Research Program on Forest, Trees and Agroforestry, has been operating since 2012. One of the objectives of the AgFor project is to empower motivated farmers of either gender to enhance and diversify the productivity and profitability of their tree-based systems. Towards achieving that objective, an AFFS was implemented from April 2013 to March 2014.

The AFFS was supported by results of a project baseline survey conducted with farmers from October to November 2012. The survey showed that more than $60 \%$ of the respondents preferred extension methods that contained practical sessions and face-to-face discussions. The concept of farmer field schools, which uses participatory training techniques to achieve learning objectives, fits well with farmers' needs for innovative extension approaches at the AgFor sites. Thus, a farmer field school concept was applied to assist the 'linking knowledge to action' process, as stated in the AgFor title.

One year after the implementation of the AFFS, an evaluation was conducted with the objective of analysing the benefits and challenges of the school implementation, based on participants' perspectives. An analysis was also conducted to understand the possibility of implementing AFFS in a broader area.

\section{Agroforestry farmer field school concepts and framework in the AgFor Project}

Training and Visits ${ }^{1}$ and Farmer Field Schools ${ }^{2}$ are two extension approaches that have been implemented in the AgFor project. Nursery establishment and management require intensive work over one-to-two years, thus, biweekly training and visits over a minimum period of one year is an appropriate extension approach to improve quality seedling production (Roshetko et

\footnotetext{
${ }^{1}$ Training and Visits is one extension approach identified by the Food and Agriculture Organization of the United Nations (FAO).

${ }^{2}$ A farmer field school is a group learning process where farmers enhance their knowledge and analytical skills through observation and experimental learning conducted over the full cycle of crop production. The concept was originally developed and tested by the FAO for controlling the use of pesticides in annual crops, particularly, rice.
} 
al 2013). However, for topics such as garden management, where the nature of perennial tree crops requires a minimum of one year post-intervention to evaluate the impact of the different management options, another extension approach is necessary that enhances farmers' analytical skills and enriches their sources of information. A modified farmer field school extension approach was expected to enhance farmers' knowledge and skills leading to increases in agroforest garden productivity, thus, an AFFS was developed through AgFor (Martini 2013).

The objectives of the AFFS were to 1) stimulate an extension approach that uses demonstration plots as places to learn new knowledge and technology; 2) provide an innovative extension approach that can enhance farmers' analytical skills and information networking and which can be continued by government extension agents; and 3) prepare expert farmers who can play a role as extension agents in the future. Besides enhancing the knowledge of farmers in managing agroforestry gardens, another expected outcome of the AFFS was positive links between farmers, government extension agents and scientists from research institutes.

A main concept of AFFS is to link knowledge produced by research institutes to farmers (Figure 1.) through participation, a key principle of AFFS, by involving research institutes, government extensionists and farmers in the entire process. Government extension agents are expected to: 1) facilitate the learning process in the field; 2) maintain facilitation of positive extension systems; and 3) keep connections with research institutes as sources of information. Training of Trainers (ToT) and Farmer to Farmer (FtF) extension are two essential processes included in the AFFS. Besides strengthening knowledge and experience, the ToT process is expected to form expert farmers who have potency as extension agents while the FtF process is expected to facilitate the formation of informal farmer information networks.

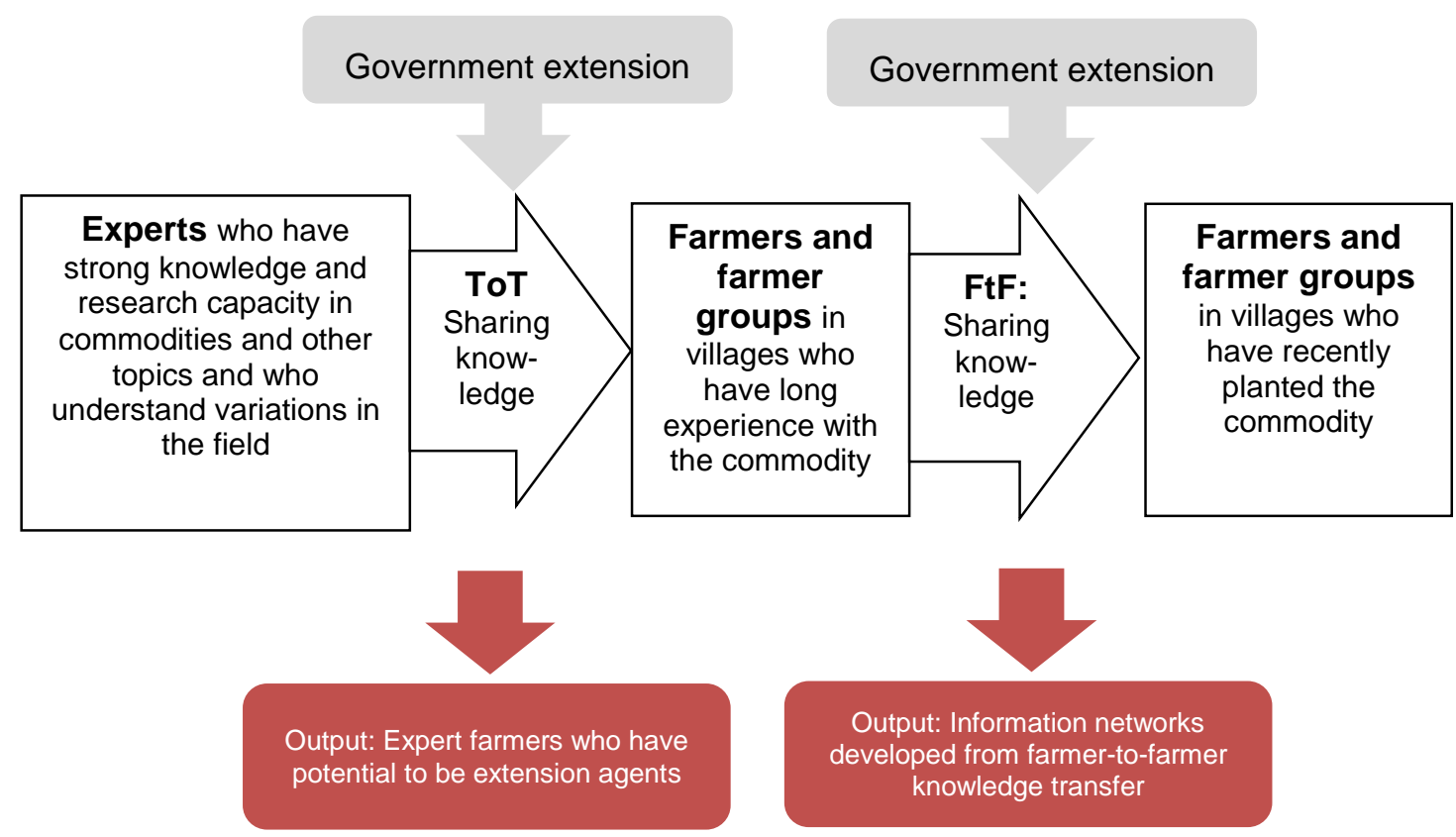

Source: Primary concept

Figure 1. Concept of AgFor's Agroforestry Farmer Field Schools for Garden Management 
A technical committee was formed before implementing the AFFS. The committee consisted of a) an agroforestry extension specialist; b) AFFS field team; c) government extension agents; and d) AFFS communication team. Detailed roles of each member of the technical committee are listed in Table 1.

Table 1. Technical committee for implementing AFFS

\begin{tabular}{|c|c|}
\hline $\begin{array}{l}\text { Technical committee } \\
\text { member }\end{array}$ & Role \\
\hline $\begin{array}{l}\text { Agroforestry } \\
\text { extension specialist }\end{array}$ & $\begin{array}{l}\text { - } \quad \text { Establish connections with research institutes } \\
\text { - } \quad \text { Design agenda and topics for the school } \\
\text { - } \quad \text { Coordinate all activities related to the school }\end{array}$ \\
\hline Field team & $\begin{array}{l}\text { - } \quad \text { Prepare schedule, venue, logistics (equipment, catering) } \\
\text { - } \quad \text { Invite all stakeholders in the village to attend the school } \\
\text { - } \quad \text { Select venues for the farmer field day } \\
\text { - } \quad \text { Prepare and select farmer demonstration trials ('demoplots') to be used as } \\
\text { - } \quad \text { Facilitate the school process } \\
\text { - } \quad \text { Monitor follow-up needs post-AFFS }\end{array}$ \\
\hline $\begin{array}{l}\text { Government } \\
\text { extension agents }\end{array}$ & $\begin{array}{l}\text { - Together with the field team, facilitate the learning process of the school } \\
\text { - } \quad \text { Transfer results from the school to government programs }\end{array}$ \\
\hline $\begin{array}{l}\text { Communication } \\
\text { team }\end{array}$ & $\begin{array}{l}\text { Together with the agroforestry extension specialist, develop extension } \\
\text { materials } \\
\text { Disseminate the results and lessons learned of the school to broader } \\
\text { audiences through mass media or other communication channels }\end{array}$ \\
\hline
\end{tabular}

In AFFS, at least five different commodities became the focus over a period of one year. Every three months, the AFFS held sessions that provided new information and perspectives related to one-to-two commodities prioritized by farmers. In each third-month session, three steps were commenced to enhance farmers' analytical skills (Table 2): 1) Strengthening the concept and knowledge through scientist-to-farmer and farmer-to-farmer extension approaches; 2) farmer field days; and 3) evaluation.

Table 2. Steps in each of AFFS 3 monthly-session

\begin{tabular}{|c|c|c|c|}
\hline Steps & Time & Objectives & Activities \\
\hline $\begin{array}{l}\text { Step 1: } \\
\text { Strengthening the } \\
\text { concept and } \\
\text { knowledge }\end{array}$ & $\begin{array}{l}\text { First } \\
\text { month }\end{array}$ & $\begin{array}{l}\text { To strengthen farmers' knowledge } \\
\text { and update external sources of } \\
\text { information on topics of } \\
\text { agroforestry management }\end{array}$ & $\begin{array}{l}\text { A one-day school in at least } \\
\text { two farmer demonstration } \\
\text { plots. Discussion, analysis } \\
\text { and practice conducted } \\
\text { through scientist-to-farmer } \\
\text { and farmer-to-farmer } \\
\text { extension approaches }\end{array}$ \\
\hline $\begin{array}{l}\text { Step 2: } \\
\text { Farmer field day }\end{array}$ & $\begin{array}{l}\text { Second } \\
\text { month }\end{array}$ & $\begin{array}{l}\text { To enhance farmers' analytical } \\
\text { skills and to expand farmers' } \\
\text { sources of information and } \\
\text { networks that can assist farmers to } \\
\text { solve problems they encounter in } \\
\text { their gardens }\end{array}$ & $\begin{array}{l}\text { A one-day school through } \\
\text { field visits to demonstration } \\
\text { plots in other villages or } \\
\text { research stations }\end{array}$ \\
\hline $\begin{array}{l}\text { Step 3: } \\
\text { Evaluation }\end{array}$ & $\begin{array}{l}\text { Third } \\
\text { month }\end{array}$ & $\begin{array}{l}\text { To reflect on how the new } \\
\text { knowledge learned from the school } \\
\text { could be applied in their gardens }\end{array}$ & $\begin{array}{l}\text { A half-day school in class. } \\
\text { Discussion about new } \\
\text { knowledge and how it can be } \\
\text { applied in gardens }\end{array}$ \\
\hline
\end{tabular}


The AFFS process was completed after one year and participants were given certificates. The AFFS follow-up continued through monitoring conducted at selected agroforestry gardens and demonstration plots established on the land of AFFS participants with the objective of learning about the adoption process and impact of the new technologies introduced through the AFFS. The selection of demonstration plots was based on farmers' willingness to test the technology in their gardens and allow the plots be used for learning during a subsequent two years.

\section{Data collection}

The AFFS was implemented at AgFor project sites in South and Southeast Sulawesi provinces. In South Sulawesi, the AFFS was implemented in seven villages located in Bantaeng District and five villages in Bulukumba District. The two districts are adjacent, with clove, coffee, cacao, durian and other tropical fruit as dominant commodities produced in agroforestry gardens being farmers' main sources of livelihoods (Khususyiah et al., 2012). In Southeast Sulawesi, the AFFS was implemented in seven villages located in Konawe and seven villages in East Kolaka districts. Konawe and East Kolaka are also adjacent to each other, with cacao, pepper, durian and teak as main commodities (Janudianto et al., 2012). Differences in number of villages per district related to the number of AgFor pilot villages located in each district.

A survey was conducted from April to July 2014 through structured interviews with 263 respondents, equalling $12 \%$ of the total participants in the AFFS (total of 1733 attendees). Respondents were randomly selected from seven villages in Bantaeng, three in Bulukumba, seven in Konawe and seven in East Kolaka. Of the total, 25\% of respondents were women, equalling the percentage of women who attended the AFFS activities. The number of respondents in South Sulawesi (150: 112 men; 38 women) was higher than the number of respondents in Southeast Sulawesi (113: 85 men; 28 women) because the number of AFFS sessions and participants was greater in South Sulawesi.

Respondents were between 17 and 70 years-old, with average age of 39 years in South Sulawesi and 42 years in Southeast Sulawesi. Most of the respondents (91\%) were farmers, with the other $9 \%$ being government extension agents, housewives, labourers (nonagricultural), school teachers and traders. Almost all the respondents (98\%) were members of AgFor farmer groups; four respondents were government extension agents and a housewife. In general, the respondents were active participants in the AgFor project.

Information collected in the study was on the type of AFFS process that was attended by respondents, the favourite AFFS activity of the respondents, the motivation of respondents to attend AFFS activities, and the type of changes in respondents' gardens resulting from participation in AFFS activities. A qualitative analysis was also conducted to identify and understand the challenges of the AFFS approach. 


\section{Results and discussion}

\subsection{AFFS implementation}

AFFS activities were held at AgFor project sites in South and Southeast Sulawesi from April 2013 to March 2014. Clove, pepper, cacao, coffee and durian were selected as the focus commodities based on farmers' prioritization (Figure 2). While nutmeg was also prioritized, particularly by farmers in South Sulawesi, there was not much new knowledge generated for nutmeg garden management. Nutmeg-related activities in AgFor focused on producing quality seedlings.

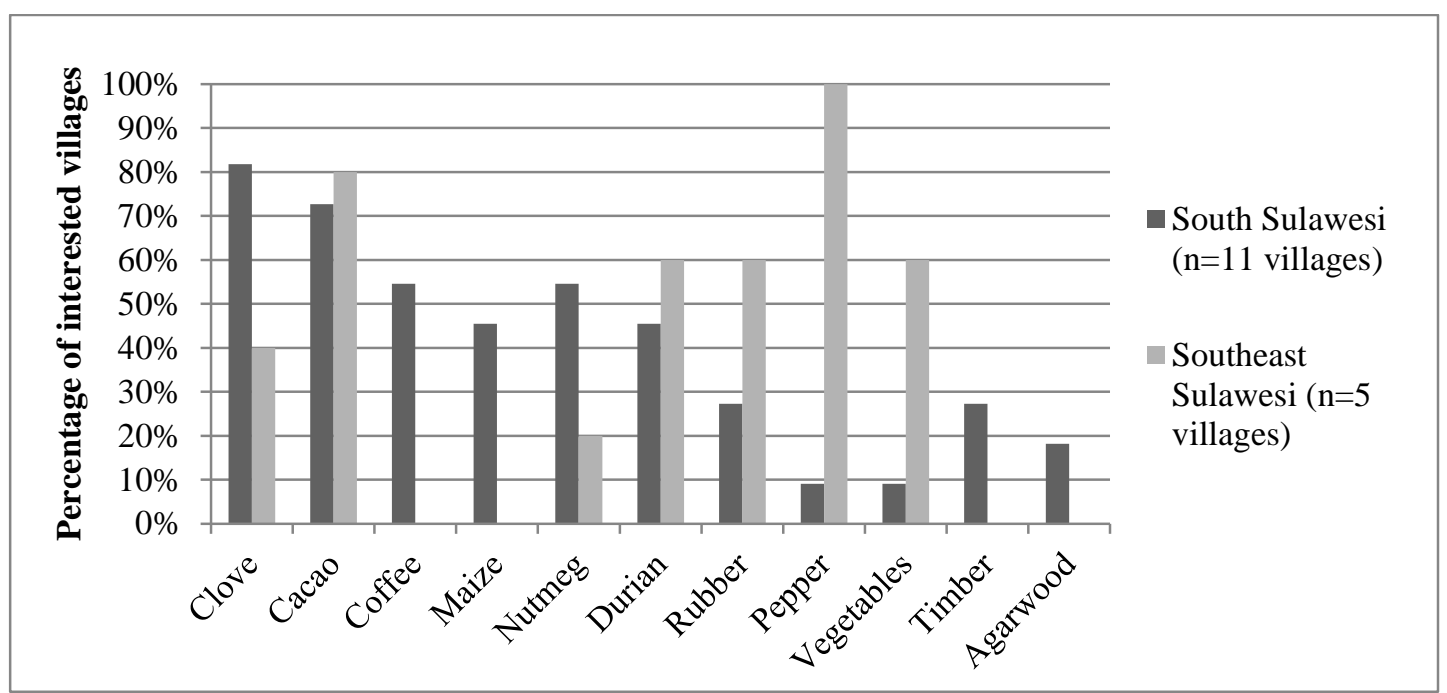

Source: Primary data from focus-group discussions in January 2013 (South Sulawesi) and February 2013 (Southeast Sulawesi)

Figure 2. Commodities proposed by farmers for inclusion in the AFFS in South Sulawesi and Southeast Sulawesi.

Based on focus-group discussions with farmers, the main topics for AFFS were set as integrated pest and disease management and garden rehabilitation. In addition, based on recommendations from experts in the prioritized commodities, information on planting, fertilizing, pruning and producing superior seedlings were also included in the AFFS.

Scientists from Indonesian national research institutes (Table 3) were engaged to share new knowledge in AFFS sessions with farmers from selected villages who had long experience with the commodity. These selected farmers were called 'village trainers' and most spoke Indonesian, the national language, fluently. Language capacity was important because not all farmers spoke Indonesian fluently but rather their own local language. One-to-two weeks after the training, the 'village trainers' would share their new knowledge with other farmers in villages that had not received visits from the scientists because the farmers were new to the commodities discussed in the training. Some of the follow-up training sessions were conducted in local languages to maximize clear communication; this was particularly necessary in Bantaeng and Bulukumba districts. 
Table 3. Resource persons for each commodity in the AFFS

\begin{tabular}{|c|c|c|}
\hline Commodity & Institution & Resource person \\
\hline Clove and pepper & $\begin{array}{l}\text { National Research Institute for Spices } \\
\text { and Medicinal plants (Balai Penelitian } \\
\text { Tanaman Rempah dan Obat/Balittro), } \\
\text { based in Bogor, West Java Province }\end{array}$ & $\begin{array}{l}\text { Dr Dyah Manohara (pepper expert) } \\
\text { Dr Dono Wahyuno (clove expert) }\end{array}$ \\
\hline Cacao and coffee & $\begin{array}{l}\text { Indonesia Coffee and Cacao } \\
\text { Research Institute (ICCRI), based in } \\
\text { Jember, East Java Province }\end{array}$ & $\begin{array}{l}\text { Dr Retno Hulupi (coffee expert) } \\
\text { Dr Adi A. Prawoto (cacao expert) }\end{array}$ \\
\hline $\begin{array}{l}\text { Durian and fruit } \\
\text { trees }\end{array}$ & $\begin{array}{l}\text { National Research Institute for } \\
\text { Tropical Fruit (Pusat Kajian Buah } \\
\text { Tropika, Institut Pertanian Bogor), } \\
\text { based in Bogor, West Java Province }\end{array}$ & $\begin{array}{l}\text { Dr Sobir } \\
\text { (tropical fruit expert) }\end{array}$ \\
\hline
\end{tabular}

After one year, the total number of AFFS participants in the two provinces was 1733 with an average budget expenditure of USD 17 per participant. The number of extension agents involved in the AFFS was 40 in Southeast Sulawesi and eight in South Sulawesi. The lower level of involvement in South Sulawesi was because most extension agents were focused on rice and vegetable production. The percentage of women participants varied based on the commodity (Table 4). In both provinces, the number of participants was highest for clove and pepper because those two crops had the highest economic values (compared to coffee, cacao, and durian).

Table 4. AFFS events conducted from April 2013 to March 2014

\begin{tabular}{|c|c|c|c|c|c|c|c|}
\hline \multirow[t]{2}{*}{ Schedule } & \multirow[t]{2}{*}{ Topics } & \multicolumn{3}{|c|}{ South Sulawesi } & \multicolumn{3}{|c|}{ Southeast Sulawesi } \\
\hline & & Men & Women & Total & Men & Women & Total \\
\hline $\begin{array}{l}\text { April- } \\
\text { September } \\
2013\end{array}$ & $\begin{array}{l}\text { Pest and disease } \\
\text { management of clove and } \\
\text { pepper in agroforests; } \\
\text { garden rejuvenation } \\
\text { strategies }\end{array}$ & $79.9 \%$ & $20.1 \%$ & 637 & $70.4 \%$ & $29.6 \%$ & 265 \\
\hline $\begin{array}{l}\text { October- } \\
\text { December } \\
2013\end{array}$ & $\begin{array}{l}\text { Coffee agroforestry } \\
\text { garden management } \\
\text { (including pests and } \\
\text { diseases and garden } \\
\text { rejuvenation strategies) }\end{array}$ & $67.2 \%$ & $32.8 \%$ & 174 & $78.8 \%$ & $21.2 \%$ & 117 \\
\hline $\begin{array}{l}\text { October- } \\
\text { December } \\
2013\end{array}$ & $\begin{array}{l}\text { Cacao agroforestry } \\
\text { garden management } \\
\text { (including pests and } \\
\text { diseases and garden } \\
\text { rejuvenation strategies) }\end{array}$ & $65.8 \%$ & $34.2 \%$ & 213 & $\mathrm{~N} / \mathrm{A}$ & $\mathrm{N} / \mathrm{A}$ & $\mathrm{N} / \mathrm{A}$ \\
\hline $\begin{array}{l}\text { February- } \\
\text { March } \\
2014\end{array}$ & $\begin{array}{l}\text { Durian and other tropical } \\
\text { fruits agroforestry garden } \\
\text { management (including } \\
\text { pests and diseases and } \\
\text { garden rejuvenation } \\
\text { strategies) }\end{array}$ & $72.5 \%$ & $27.5 \%$ & 174 & $74.8 \%$ & $25.2 \%$ & 153 \\
\hline
\end{tabular}

An AFFS on cacao was not implemented in Southeast Sulawesi because intense cacao extension activities had been provided by government extension agents through various cacao garden management programs, such as the national cacao improvement program (Gernas 
Kakao) and the Sulawesi Rainfed Agriculture Development Project of the Asian Development Bank. Instead, the AFFS was focused on how Southeast Sulawesi farmers could best use their knowledge of other priority species to enrich their cacao agroforestry garden.

\subsection{AFFS outputs and outcomes}

AFFS activities in South and Southeast Sulawesi provinces has resulted 3 main outputs:

1) Thirty-five (35) expert farmers from four districts - 17 farmers in South Sulawesi (10 men and four women in Bantaeng and three men in Bulukumba) and 18 farmers in Southeast Sulawesi (seven men in Konawe and six men and three women in East Kolaka) —were formed. Additionally, two government extension agents in Southeast Sulawesi (one each from Konawe and East Kolaka), who followed all five AFFS activities, became key partners in improving agroforestry systems in the area.

2) Farmer demonstration trials were established. Based on a participatory process, 109 farmer demonstration trials (FDTs) or demoplots were proposed as part of follow-up from the AFFS. Subsequently, 99 of the FDTs were established: 71 in South Sulawesi and 28 in Southeast Sulawesi. Monitoring of these plots has been conducted every three months since November 2013.

3) Extension materials (booklets) were produced through collaboration with resource persons in the AFFS. The communication team assisted with editing and printing the booklets. The five booklets covered pepper (Manohara and Wahyuno 2013), clove (Wahyuno and Martini 2015), durian (Sobir and Martini 2014), coffee (Hulupi and Martini 2013) and cacao (Prawoto and Martini 2014). The booklets were distributed to farmers and extension agents and are available through the project to all interested parties.

Outcomes of AFFS implementation in South and Southeast Sulawesi were mainly grouped into 3 main topics:

1) Farmers and extension agents had enhanced knowledge of agroforestry management of the five priority commodities: coffee, cacao, clove, pepper and durian. All participants received certificates acknowledging their completion of the AFFS.

2) Enhanced links between farmers, extension agents and researchers were created. Communication between researchers and farmers via SMS and phone had become common and was expanding. At the end of each AFFS session, the researchers enthusiastically gave their phone numbers to the participants to encourage more information exchange. 
3) Farmers' information networks on agroforestry technologies were expanded. Visits to successful agroforestry farmers provided good opportunities for farmers to expand their information networks about agroforestry technologies implemented in places other than their village. Farmers exchanged phone number during the visits to maintain communication with successful farmers outside their village.

\subsection{AFFS evaluation}

\subsubsection{Topics and extension methods attended and preferred by respondents}

Of the total number of survey respondents, $52 \%$ attended scientist-to-farmer sessions of the AFFS, 36\% farmer-to-farmer sessions and 12\% visit sessions. Of the total respondents (263 persons), $27 \%$ attended the pepper AFFS, $25 \%$ clove, $18 \%$ durian, $17 \%$ coffee and $13 \%$ cacao. The higher attendance at pepper and clove AFFS was because very few extension services in either province focused on these commodities.

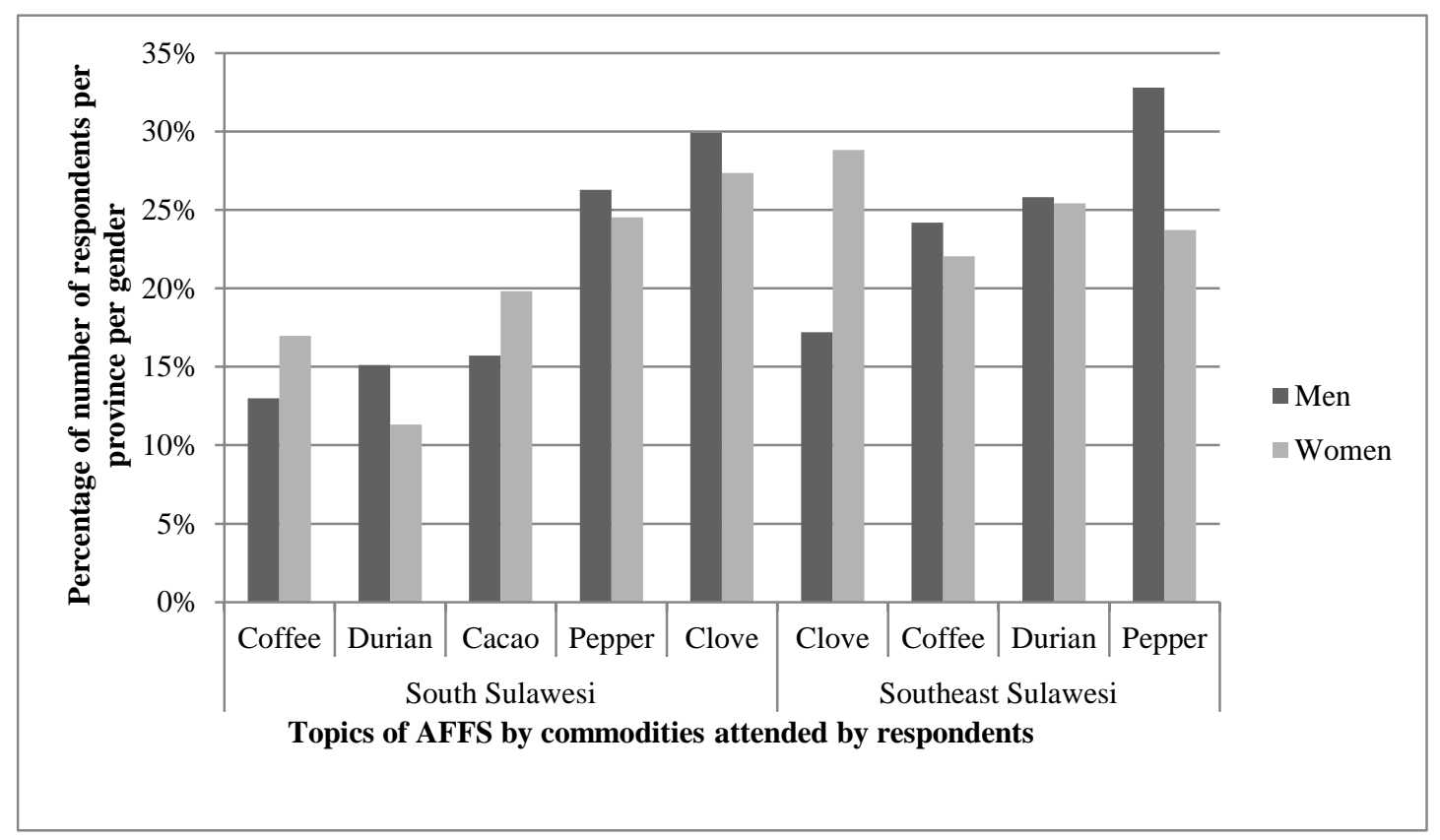

Note: number of respondents in South Sulawesi ( $\mathrm{n}$ men $=112, \mathrm{n}$ women=38), in Southeast Sulawesi ( $\mathrm{n}$ men $=85, \mathrm{n}$ women 28).

Figure 3. Topic of AFFS by commodities attended by respondents per province per gender

In South Sulawesi, both genders had high attendance at the clove AFFS because of the high price of clove motivating farmers to obtain greater knowledge of how to enhance yields (Figure 3). For the same reason, both genders in Southeast Sulawesi had high attendance at the pepper AFFS pepper. In Southeast Sulawesi, there was a clear gender difference in attendance at the clove AFFS, with nearly two-thirds of the participants being women. The lower male attendance was because clove was a new commodity there and some of the male 
farmers were not sure if local climatic and soil conditions were suitable for clove while female farmers were interested in clove owing to its high economic value. For durian, in Southeast Sulawesi market price and demand was growing, thus, farmers were willing to invest in durian, including attending the AFFS. The prices of clove and pepper were the highest of all commodities that were the focus of the AFFS: for clove reaching USD 12 per kg of dried flowers; USD 9 per kg of dried fruit for pepper; USD 2-8 USD per fruit for durian; USD 2.5 USD per kg dried beans for cacao; and USD 0.3 USD per kg dried beans for coffee. In conclusion, for AFFS topics in South and Southeast Sulawesi, farmers' attendance was highest if the focal species had high prices or strong market demand.

Besides commodity topics, we also analyzed the various extension methods used in AFFS (Figure 4). In South Sulawesi, attendance level by gender was similar for both farmer-tofarmer and scientist-to-farmer sessions. However, women's attendance on cross visits was lower because women were less willing to travel far from their home owing to their domestic responsibilities of children and household care. Although in Southeast Sulawesi women had slightly higher attendance on cross visits mostly because they were migrants who were familiar with travel from place to place. Comparison at the provincial level showed higher attendance at scientist-to-farmers sessions in Southeast Sulawesi because participants preferred to receive new information from scientists who were perceived as more reliable and having up-to-date knowledge. In South Sulawesi, the farmer-to-farmer method had the highest attendance owing to the language barrier; many farmers were not fluent in, or confident in using, Indonesian, thus, it was difficult for them to understand explanations given by the scientists.

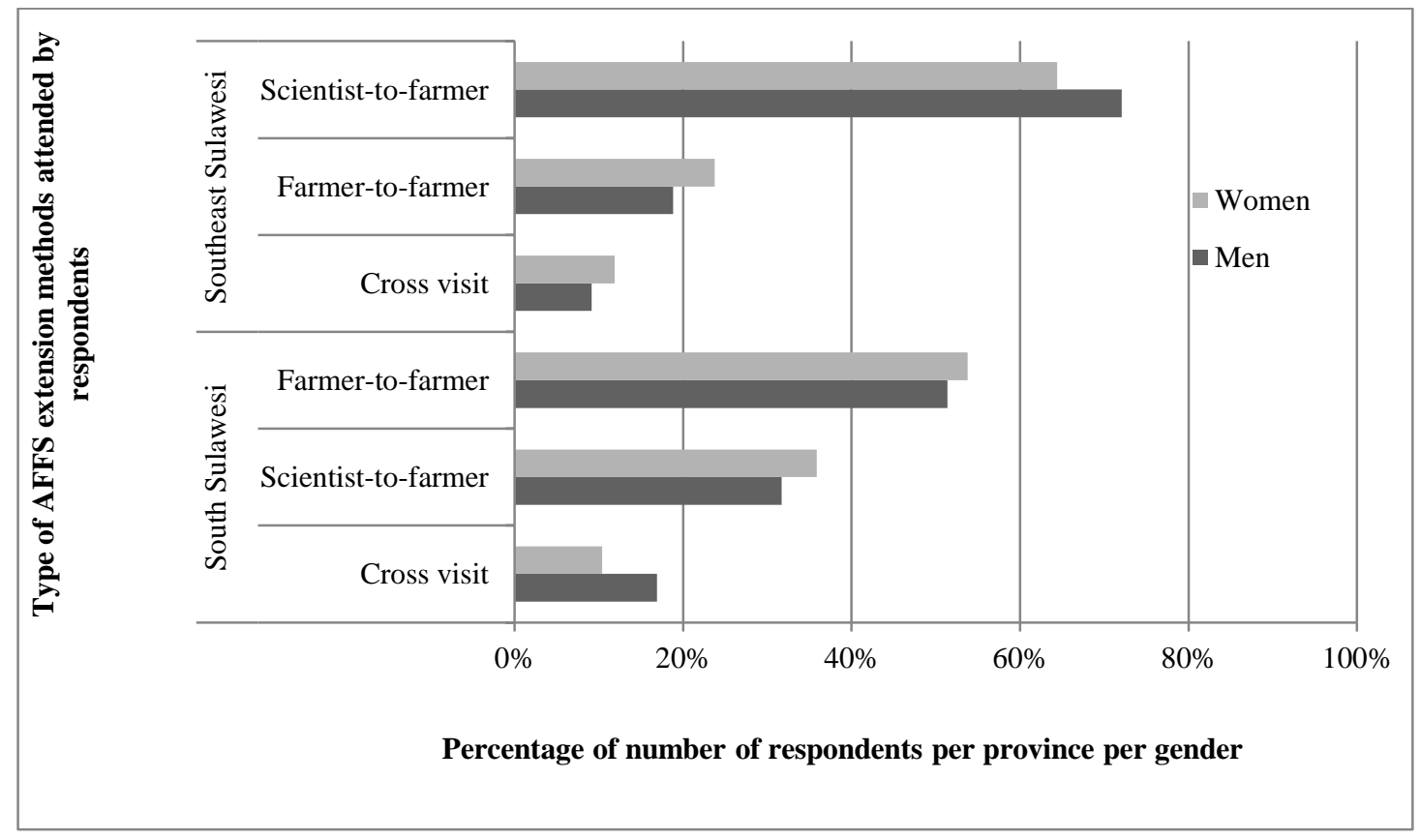

Note: number of respondents in South Sulawesi ( $\mathrm{n}$ men = 112; $\mathrm{n}$ women=38); in Southeast Sulawesi ( $\mathrm{n}$ men= 85; $\mathrm{n}$ women 28)

Figure 4. Extension method of AFFS attended by respondents per province per gender 
Respondents were asked to identify their favourite topics and extension methods. The results in South Sulawesi showed, clove, cacao and coffee, respectively, were the three most favourite topics. Clove was favoured because of the high and stable price while cacao and coffee were favoured because they had been grown in the area for a long time and made a substantial contribution to local livelihoods. While in Southeast Sulawesi, pepper, durian and coffee were the most favourite topics. Pepper and coffee were favoured because there was a lack of good quality seedlings for these species and farmers wanted to explore techniques for providing seedlings. Durian was favoured because it had good market potential, particularly, in Southeast Sulawesi.

Farmer-to-farmer was the favourite method followed by scientist-to-farmer and visits, respectively. Farmer-to-farmer was preferred because it provided practical demonstrations, easy-to-understand technical information and the language (speaking style) was easily comprehensible. Scientist-to-farmer was liked because it provided new and reliable information from scientists, provided practical demonstrations and the scientists explained in language and approach that was easy to be understood by farmers. Cross-visits had the advantage that the people visited spoke the local language, which was easily understood; also, farmers could have direct observation and discussion in the field.

\subsubsection{Motivation of respondents in attending AFFS}

Most respondents (86\%) were motivated to attend AFFS to obtain new knowledge; $12 \%$ because they were invited by the organizer; and $2 \%$ because invited by a friend and wanted to expand their networks by learning from successful farmers who attended the AFFS.

When comparing provinces, Southeast Sulawesi respondents' motivation for attending AFFS sessions was slightly more diverse than in South Sulawesi (Figure 5). In South Sulawesi, the percentage of respondents who attended because they were invited by the organizer was higher than in Southeast Sulawesi, thus, we could conclude that providing formal invitations to farmers can enhance attendance. Women seem to have had higher internal motivation to attend the AFFS (that is, obtaining new knowledge). While for men, besides internal motivation, external motivation such as an invitation from the organizer or a friend was also important.

There was no significant difference in the motivation of farmers and extension agents in attending the AFFS; all were primarily attracted to obtain new knowledge. However, with government extension agents, their main motivation was being invited by the organizer. Thus, clearly stating that new knowledge will be provided is very important for attracting farmers to an AFFS. 


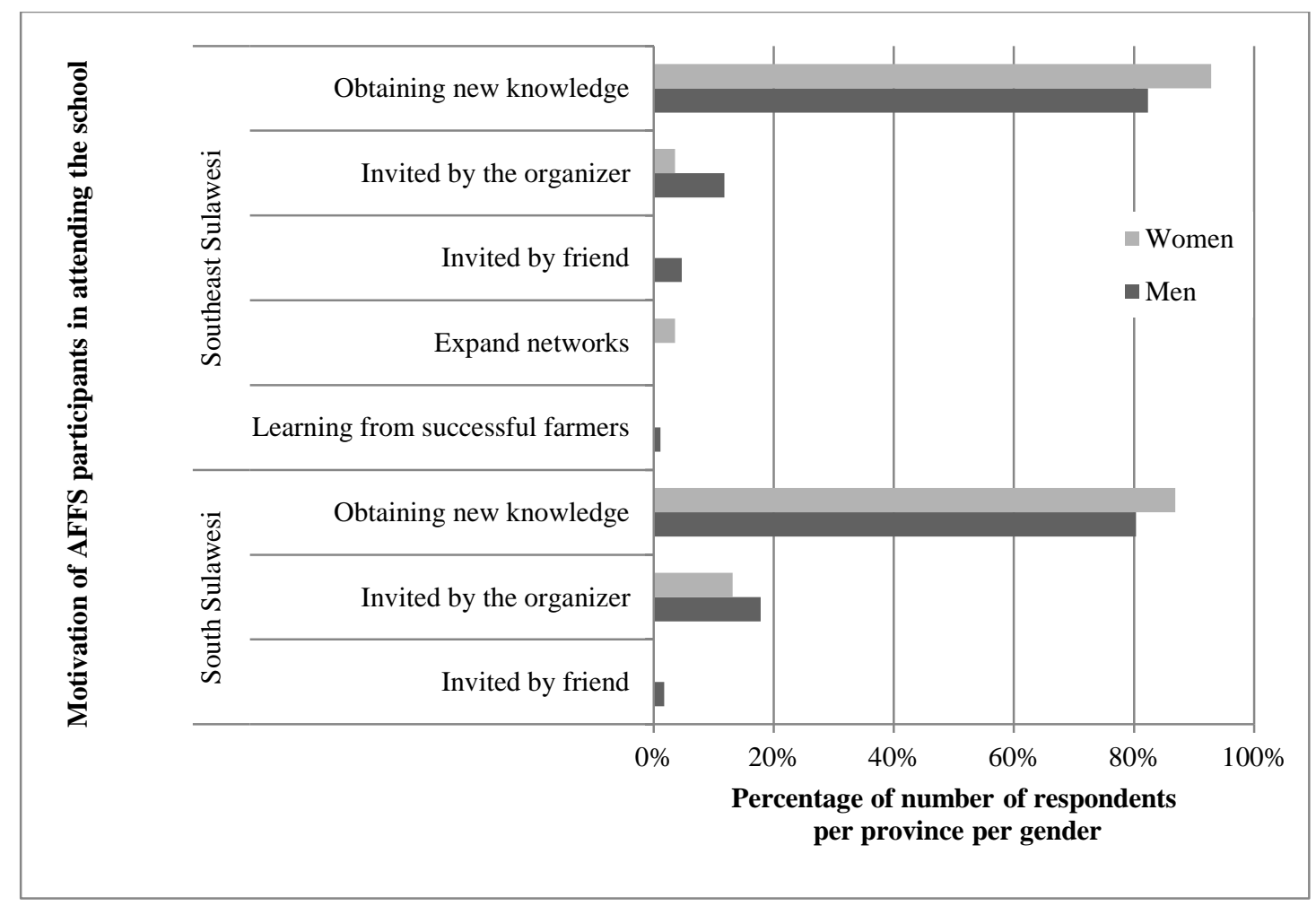

Note: number of respondents in South Sulawesi $(\mathrm{n}$ men = 112; $\mathrm{n}$ women $=38)$; in Southeast Sulawesi $(\mathrm{n}$ men = 85; $\mathrm{n}$ women $=28$ )

Figure 5. Motivation of AFFS participants in attending per province per gender

\subsubsection{Benefits of AFFS based on respondents' perspectives}

Benefits gained by respondents from the AFFS were new knowledge (70\%), improved yields (17\%), increased income ( $8 \%$ ) and improved motivation (2\%). A small number of respondents $(3 \%)$ felt they did not get any benefit from attending. There was no difference between farmers and extension agents regarding benefits gained.

Respondents who felt they did not benefit from AFFS were higher in women (4\%) than men (1\%). This may because in some areas women are not the main actors in garden management and, thus, the knowledge gained is less applicable. Only men reported improved motivation to manage their gardens as a benefit from AFFS; this likely relates to men being the main decision-makers regarding garden management in both provinces.

New knowledge was perceived as the greatest benefit received from attending AFFS. Some respondents also cited some improvements in their income and yields, which, however, were not large because the AFFS had been completed only one year to a couple of months before the evaluation, which was not long enough to see major changes in tree yields or farmers' incomes.

In Southeast Sulawesi, respondents identified nursery management and vegetative propagation as important new knowledge received from attending the AFFS (Figure 6). Interestingly, women and men held different perceptions regarding vegetative propagation and nursery management. Women were more interested in vegetative propagation than men whereas men were more interested in nursery establishment and management than women. 
Farmers in Southeast Sulawesi still depended on seedling sources that were outside the province, that is, from Bali, South Sulawesi and Java (Angreiny et al., 2014).

In South Sulawesi, pruning and fertilizing were the most important new knowledge topics reported by respondents (Figure 6). Interestingly, women saw spacing as important knowledge while it was not so important for men. These priorities were complementary and logical; both genders reported that women reminded men to use the recommended spacing, otherwise the men would not prioritize it.

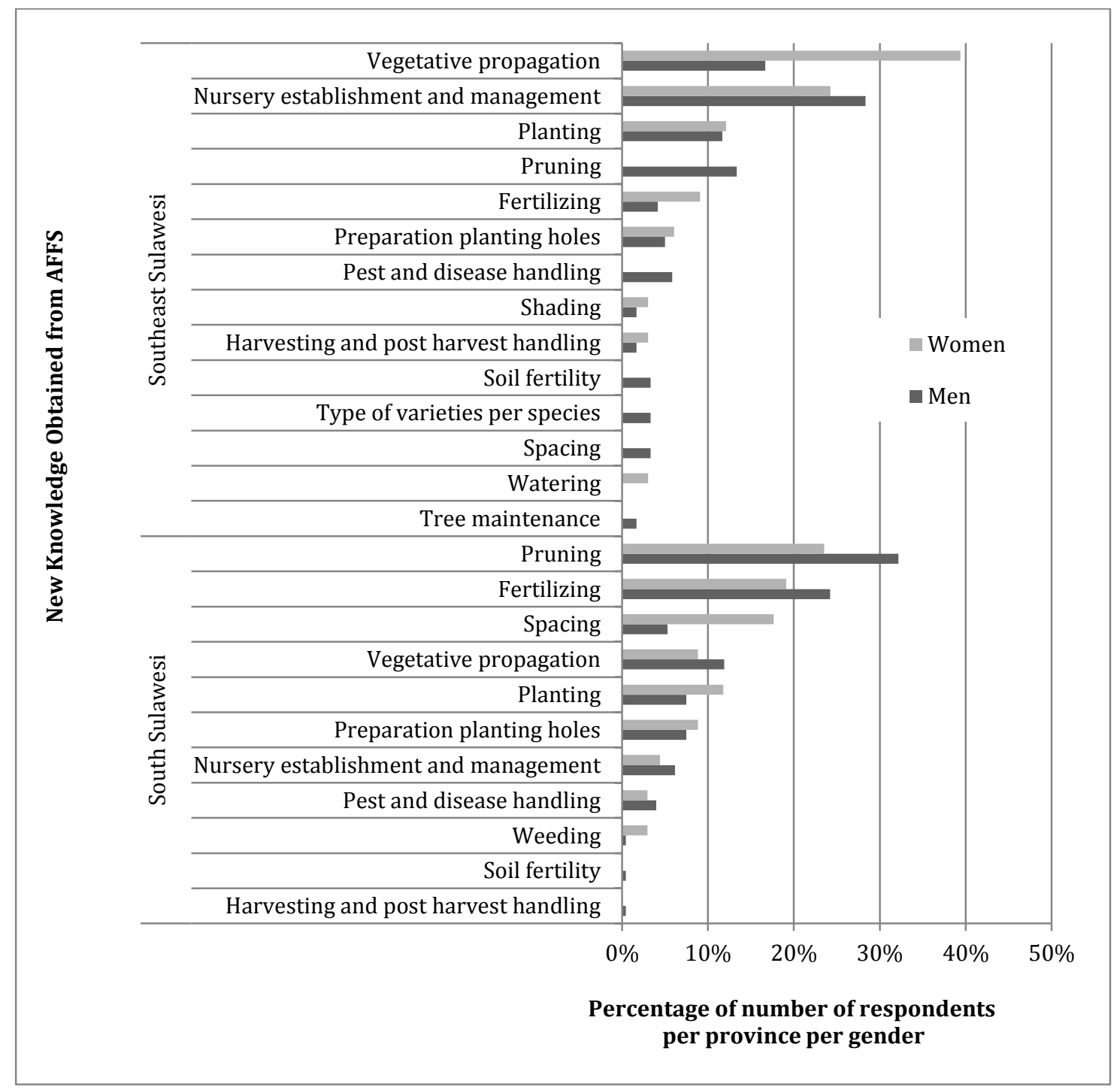

Figure 6. Type of new knowledge obtained by AFFS participants per province per gender

Even though the AFFS was completed only a year or less before the evaluation, some farmers attributed increased yields and incomes to adopting knowledge gained at the AFFS, that is, 33 respondents in South Sulawesi and five in Southeast Sulawesi (Table 5). Improvement in yields depends on the technology tested and level of adoption because not all respondents adopt $100 \%$ of the introduced technologies. In both provinces, yield improvement resulted from testing pruning and fertilizing techniques. Respondents in both provinces also succeeded in producing superior quality seedlings - particularly, for durian and pepper-with $90 \%$ of the seedlings produced for their own use, with the balance sold locally. 
Table 5. Improvement in yields from introduced new technology in AFFS based on farmers perspectives

\begin{tabular}{|c|c|c|}
\hline Provinces & Technology introduced & Increased yields \\
\hline \multirow{7}{*}{$\begin{array}{l}\text { South } \\
\text { Sulawesi }\end{array}$} & Pruning cacao ( $n=18: 14$ men, 4 women) & $1-100 \mathrm{~kg}$ dried cacao beans/ha \\
\hline & Pruning coffee ( $\mathrm{n}=5: 4$ men, 1 woman) & $\begin{array}{c}300-600 \mathrm{~L} \text { dried coffee beans/ha }(5 \mathrm{~L} \\
\text { dried coffee beans/tree) }\end{array}$ \\
\hline & Fertilizing coffee ( $n=1$ woman) & 200 L dried coffee beans/ha \\
\hline & Fertilizing clove ( $n=2$ men) & $100 \mathrm{~kg}$ dried clove flowers/ha (4 L/tree) \\
\hline & Side-grafting cacao ( $n=1$ man) & $0.5 \mathrm{~kg}$ dried cacao beans/tree \\
\hline & Vegetative propagation durian ( $\mathrm{n}=1$ man) & 10 durian superior seedlings \\
\hline & Pepper nursery ( $\mathrm{n}=5$ men) & 30-300 pepper superior seedlings \\
\hline \multirow{5}{*}{$\begin{array}{l}\text { Southeast } \\
\text { Sulawesi }\end{array}$} & Pepper pruning ( $\mathrm{n}=1 \mathrm{man})$ & 10 dried $\mathrm{kg} / \mathrm{ha}$ \\
\hline & Fertilizing ( $\mathrm{n}=1$ man) & 3 dried $\mathrm{kg} / \mathrm{ha}$ \\
\hline & Soil fertility ('rorak') (n=1 man) & 60 dried $\mathrm{kg} / \mathrm{ha}$ \\
\hline & Vegetative propagation durian ( $\mathrm{n}=1$ man) & 100 durian superior seedlings \\
\hline & Pepper nursery ( $n=1$ man) & 300 pepper superior seedlings \\
\hline
\end{tabular}

In South Sulawesi, most monetary benefit (average IDR 3,000,000 ( \pm USD 280$)$ ) was received from improvement in fertilizing techniques applied to clove systems; the second highest (average IDR 800,000 ( \pm USD 72$)$ ) was from improvement of pruning techniques applied in coffee and cacao systems (Figure 7). Respondents also received minimal monetary benefit from seedling production and side-grafting cacao. Most of the seedlings produced were used to enrich farmers' gardens. Side-grafting of mature trees had not yet yielded significant increases in production.

In Southeast Sulawesi, the greatest monetary benefit was from improvement of pruning in pepper systems (IDR 1,100,000 ( \pm USD 100)) and improvement of soil fertility ('rorak' technique $^{3}$ ) applied to cacao systems (IDR 1,120,000 ( \pm USD 101)). Some monetary benefit was also received from vegetative propagation of durian seedlings (IDR 600,000 ( \pm USD 55)) and selection of superior pepper germplasm (IDR 500,000 ( \pm USD 45)).

\footnotetext{
${ }^{3}$ The 'rorak' technique, which is a technique used to improve soil aeration and rejuvenate roots by digging a hole with distance $50 \mathrm{~cm}$ from the tree trunk. The hole size is $60 \mathrm{~cm}$ depth, $80 \mathrm{~cm}$ length, $30 \mathrm{~cm}$ width. This technique was recommended for coffee but some farmers also applied it to cacao.
} 


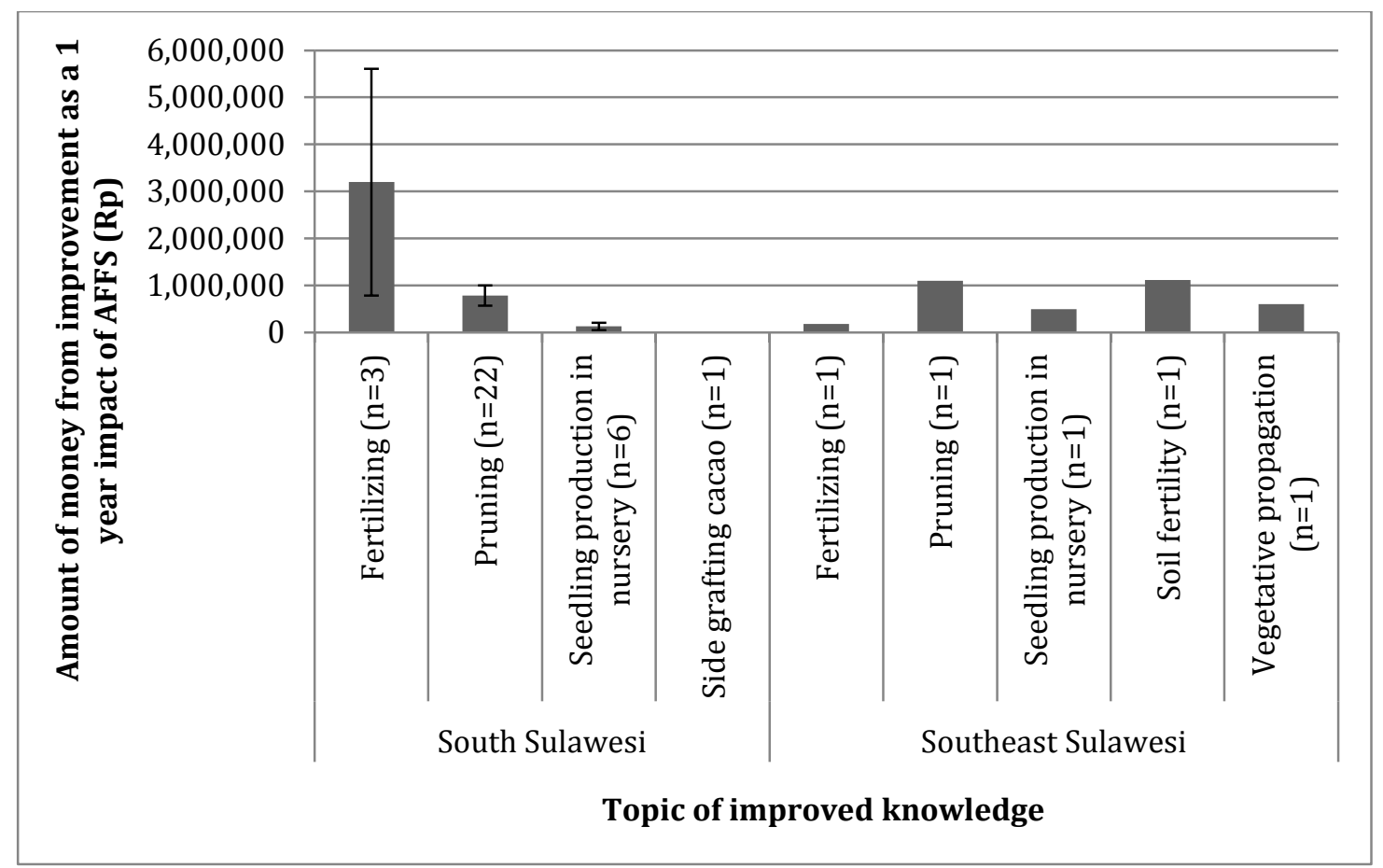

Note: USD $1=$ IDR 11,000

Figure 7. Amount of money received from improvements made by respondents in their gardens with the information and knowledge they received from the AFFS

From the results above, it is clear that the AFFS provided short-term benefit in the form of new knowledge and greater motivation and long-term benefit through improved yields and income. While these initial short-term benefits were impressive and participants were pleased with the AFFS, they acknowledged that sustained long-term benefits were necessary for the new knowledge provided through the AFFS to be fully integrated into farmers' standard management practices. Otherwise, the new knowledge might be forgotten. Further facilitation was necessary to consolidate benefits. Thus, AgFor continues to strengthen the learning process via regular visits by the AgFor team, who monitor the demoplots and provide personal consultations with the owners of the plots every three months for two years. There are 71 farmer demoplots in South Sulawesi and 28 in Southeast Sulawesi. In the second year, those plots will be evaluated in order to identify and share the impact of adopting new knowledge on improved yields and income. 


\section{Conclusion}

The evaluation of the AFFS one year after implementation showed that most of the respondents felt they gained knowledge and other benefits from AFFS. Farmers' attendance and interest in AFFS was highest when the focal species had a high price or good market potential. New and reliable information was the most important aspect of AFFS that attracted farmers to attend and then test the new knowledge they received. Benefits received by respondents after one year can be divided into short term — obtaining new knowledge — and long term: improved yields and income. Fourteen percent (14\%) of the respondents gained monetary benefit from applying the new knowledge. In the following one or two years, there might be more or less respondents applying the knowledge they gained from AFFS. Thus, it is important that after AFFS ends to implement a facilitation strategy by the AgFor project in collaboration with government extension agents to promote continued testing by farmers of the new knowledge they received from the AFFS. 


\section{References}

Angreiny Y, Martini E, Said L, Roshetko JM. 2014. Nursery as alternative source of livelihood in Southeast Sulawesi: potentials and challenges. Paper presented at National Agroforestry Conference V, Ambon, Indonesia, 21 November 2014.

Hulupi R, Martini E. 2013. Pedoman budi daya dan pemeliharaan tanaman kopi di kebun campur. Guidelines for coffee cultivation and maintenance in mixed gardens. Bogor, Indonesia: World Agroforestry Centre (ICRAF) Southeast Asia Regional Program.

Janudianto, Khususiyah N, Isnurdiansyah, Suyanto, Roshetko JM. 2012. Agroforestry and Forestry in Sulawesi series: livelihood strategies and land-use system dynamics in Southeast Sulawesi. Working paper 156. Bogor, Indonesia: World Agroforestry Centre (ICRAF). http://www.worldagroforestry.org/downloads/publications/PDFs/WP12055.PDF

Khususiyah N, Janudianto, Isnurdiansyah, Suyanto, Roshetko JM. 2012. Agroforestry and Forestry in Sulawesi series: livelihood strategies and land-use system dynamics in South Sulawesi. Working paper 155. Bogor, Indonesia: World Agroforestry Centre (ICRAF). http://www.worldagroforestry.org/WP12054.PDF

Manohara D, Wahyuno D. 2013. Pedoman budidaya merica. Guidelines for pepper cultivatio). Bogor, Indonesia: World Agroforestry Centre (ICRAF) Southeast Asia Regional Program.

Martini E. 2013. Farmers' potentials role in agricultural extension:Agroforestry Farmer Field School Experiences in Sulawesi, Indonesia. Poster presented at Global Forum for Rural Advisory Services (GFRAS) 4th Annual Meeting in Berlin, Germany on September 2013.

Prawoto AA, Martini E. 2014. Pedoman budi daya kakao pada kebun campur. Guidelines for cacao cultivation in mixed gardens. Bogor, Indonesia: World Agroforestry Centre (ICRAF) Southeast Asia Regional Program.

Roshetko JM, Idris N, Purnomosidhi P, Zulfadhli T, Tarigan J. 2013. Farmer extension approach to rehabilitate smallholder fruit agroforestry systems: the Nurseries of excellence (NOEL) program in Aceh, Indonesia. Acta Horticultura (ISHS) 975:649-656. http://www.actahort.org/books/975/975_81.htm

Sobir, Martini E. 2015. Pedoman durian dan rambutan pada kebun campur. Guidelines for durian and rambutan cultivation in mixed gardens. Bogor, Indonesia: World Agroforestry Centre (ICRAF) Southeast Asia Regional Program.

Wahyuno D, Martini E. 2015. Pedoman budi daya cengkeh pada kebun campur. Guidelines for clove cultivation in mixed gardens. Bogor, Indonesia: World Agroforestry Centre (ICRAF) Southeast Asia Regional Program. 


\section{WORKING PAPERS WITH DOIS}

\section{5}

1. Agroforestry in the drylands of eastern Africa: a call to action

2. Biodiversity conservation through agroforestry: managing tree species diversity within a network of community-based, nongovernmental, governmental and research organizations in western Kenya.

3. Invasion of prosopis juliflora and local livelihoods: Case study from the Lake Baringo area of Kenya

4. Leadership for change in farmers organizations: Training report: Ridar Hotel, Kampala, 29th March to 2nd April 2005.

5. Domestication des espèces agroforestières au Sahel : situation actuelle et perspectives

6. Relevé des données de biodiversité ligneuse: Manuel du projet biodiversité des parcs agroforestiers au Sahel

7. Improved land management in the Lake Victoria Basin: TransVic Project's draft report.

8. Livelihood capital, strategies and outcomes in the Taita hills of Kenya

9. Les espèces ligneuses et leurs usages: Les préférences des paysans dans le Cercle de Ségou, au Mali

10. La biodiversité des espèces ligneuses: Diversité arborée et unités de gestion du terroir dans le Cercle de Ségou, au Mali

\section{6}

11. Bird diversity and land use on the slopes of Mt. Kilimanjaro and the adjacent plains, Tanzania

12. Water, women and local social organization in the Western Kenya Highlands

13. Highlights of ongoing research of the World Agroforestry Centre in Indonesia

14. Prospects of adoption of tree-based systems in a rural landscape and its likely impacts on carbon stocks and farmers' welfare: The FALLOW Model Application in Muara Sungkai, Lampung, Sumatra, in a 'Clean Development Mechanism' context

15. Equipping integrated natural resource managers for healthy Agroforestry landscapes.

17. Agro-biodiversity and CGIAR tree and forest science: approaches and examples from Sumatra.

18. Improving land management in eastern and southern Africa: A review of policies.

19. Farm and household economic study of Kecamatan Nanggung, Kabupaten Bogor, Indonesia: A socioeconomic base line study of Agroforestry innovations and livelihood enhancement.

20. Lessons from eastern Africa's unsustainable charcoal business.

21. Evolution of RELMA's approaches to land management: Lessons from two decades of research and development in eastern and southern Africa

22. Participatory watershed management: Lessons from RELMA's work with farmers in eastern Africa.

23. Strengthening farmers' organizations: The experience of RELMA and ULAMP.

24. Promoting rainwater harvesting in eastern and southern Africa.

25. The role of livestock in integrated land management.

26. Status of carbon sequestration projects in Africa: Potential benefits and challenges to scaling up.

27. Social and Environmental Trade-Offs in Tree Species Selection: A Methodology for Identifying Niche Incompatibilities in Agroforestry [Appears as AHI Working Paper no. 9]

28. Managing tradeoffs in agroforestry: From conflict to collaboration in natural resource management. [Appears as AHI Working Paper no. 10]

29. Essai d'analyse de la prise en compte des systemes agroforestiers pa les legislations forestieres au Sahel: Cas du Burkina Faso, du Mali, du Niger et du Senegal.

30. Etat de la recherche agroforestière au Rwanda etude bibliographique, période 1987-2003 
31. Science and technological innovations for improving soil fertility and management in Africa: A report for NEPAD's Science and Technology Forum.

32. Compensation and rewards for environmental services.

33. Latin American regional workshop report compensation.

34. Asia regional workshop on compensation ecosystem services.

35. Report of African regional workshop on compensation ecosystem services.

36. Exploring the inter-linkages among and between compensation and rewards for ecosystem services CRES and human well-being

37. Criteria and indicators for environmental service compensation and reward mechanisms: realistic, voluntary, conditional and pro-poor

38. The conditions for effective mechanisms of compensation and rewards for environmental services.

39. Organization and governance for fostering Pro-Poor Compensation for Environmental Services.

40. How important are different types of compensation and reward mechanisms shaping poverty and ecosystem services across Africa, Asia \& Latin America over the Next two decades?

41. Risk mitigation in contract farming: The case of poultry, cotton, woodfuel and cereals in East Africa.

42. The RELMA savings and credit experiences: Sowing the seed of sustainability

43. Yatich J., Policy and institutional context for NRM in Kenya: Challenges and opportunities for Landcare.

44. Nina-Nina Adoung Nasional di So! Field test of rapid land tenure assessment (RATA) in the Batang Toru Watershed, North Sumatera.

45. Is Hutan Tanaman Rakyat a new paradigm in community based tree planting in Indonesia?

46. Socio-Economic aspects of brackish water aquaculture (Tambak) production in Nanggroe Aceh Darrusalam.

47. Farmer livelihoods in the humid forest and moist savannah zones of Cameroon.

48. Domestication, genre et vulnérabilité : Participation des femmes, des Jeunes et des catégories les plus pauvres à la domestication des arbres agroforestiers au Cameroun.

49. Land tenure and management in the districts around Mt Elgon: An assessment presented to the Mt Elgon ecosystem conservation programme.

50. The production and marketing of leaf meal from fodder shrubs in Tanga, Tanzania: A pro-poor enterprise for improving livestock productivity.

51. Buyers Perspective on Environmental Services (ES) and Commoditization as an approach to liberate ES markets in the Philippines.

52. Towards Towards community-driven conservation in southwest China: Reconciling state and local perceptions.

53. Biofuels in China: An Analysis of the Opportunities and Challenges of Jatropha curcas in Southwest China.

54. Jatropha curcas biodiesel production in Kenya: Economics and potential value chain development for smallholder farmers

55. Livelihoods and Forest Resources in Aceh and Nias for a Sustainable Forest Resource Management and Economic Progress

56. Agroforestry on the interface of Orangutan Conservation and Sustainable Livelihoods in Batang Toru, North Sumatra.

57. Assessing Hydrological Situation of Kapuas Hulu Basin, Kapuas Hulu Regency, West Kalimantan. 
58. Assessing the Hydrological Situation of Talau Watershed, Belu Regency, East Nusa Tenggara.

59. Kajian Kondisi Hidrologis DAS Talau, Kabupaten Belu, Nusa Tenggara Timur.

60. Kajian Kondisi Hidrologis DAS Kapuas Hulu, Kabupaten Kapuas Hulu, Kalimantan Barat.

61. Lessons learned from community capacity building activities to support agroforest as sustainable economic alternatives in Batang Toru orang utan habitat conservation program (Martini, Endri et al.)

62. Mainstreaming Climate Change in the Philippines.

63. A Conjoint Analysis of Farmer Preferences for Community Forestry Contracts in the Sumber Jaya Watershed, Indonesia.

64. The highlands: a shared water tower in a changing climate and changing Asia

65. Eco-Certification: Can It Deliver Conservation and Development in the Tropics.

66. Designing ecological and biodiversity sampling strategies. Towards mainstreaming climate change in grassland management.

67. Towards mainstreaming climate change in grassland management policies and practices on the Tibetan Plateau

68. An Assessment of the Potential for Carbon Finance in Rangelands

69 ECA Trade-offs Among Ecosystem Services in the Lake Victoria Basin.

69. The last remnants of mega biodiversity in West Java and Banten: an in-depth exploration of RaTA (Rapid Land Tenure Assessment) in Mount Halimun-Salak National Park Indonesia

70. Le business plan d'une petite entreprise rurale de production et de commercialisation des plants des arbres locaux. Cas de quatre pépinières rurales au Cameroun.

71. Les unités de transformation des produits forestiers non ligneux alimentaires au Cameroun. Diagnostic technique et stratégie de développement Honoré Tabuna et Ingratia Kayitavu.

72. Les exportateurs camerounais de safou (Dacryodes edulis) sur le marché sous régional et international. Profil, fonctionnement et stratégies de développement.

73. Impact of the Southeast Asian Network for Agroforestry Education (SEANAFE) on agroforestry education capacity.

74. Setting landscape conservation targets and promoting them through compatible land use in the Philippines.

75. Review of methods for researching multistrata systems.

76. Study on economical viability of Jatropha curcas L. plantations in Northern Tanzania assessing farmers' prospects via cost-benefit analysis

77. Cooperation in Agroforestry between Ministry of Forestry of Indonesia and International Center for Research in Agroforestry

78. "China's bioenergy future. an analysis through the Lens if Yunnan Province

79. Land tenure and agricultural productivity in Africa: A comparative analysis of the economics literature and recent policy strategies and reforms

80. Boundary organizations, objects and agents: linking knowledge with action in Agroforestry watersheds

81. Reducing emissions from deforestation and forest degradation (REDD) in Indonesia: options and challenges for fair and efficient payment distribution mechanisms

\section{9}

82. Mainstreaming climate change into agricultural education: challenges and perspectives

83. Challenging conventional mindsets and disconnects in conservation: the emerging role of ecoagriculture in Kenya's landscape mosaics 
84. Lesson learned RATA garut dan bengkunat: suatu upaya membedah kebijakan pelepasan kawasan hutan dan redistribusi tanah bekas kawasan hutan

85. The emergence of forest land redistribution in Indonesia

86. Commercial opportunities for fruit in Malawi

87. Status of fruit production processing and marketing in Malawi

88. Fraud in tree science

89. Trees on farm: analysis of global extent and geographical patterns of agroforestry

90. The springs of Nyando: water, social organization and livelihoods in Western Kenya

91. Building capacity toward region-wide curriculum and teaching materials development in agroforestry education in Southeast Asia

92. Overview of biomass energy technology in rural Yunnan (Chinese - English abstract)

93. A pro-growth pathway for reducing net GHG emissions in China

94. Analysis of local livelihoods from past to present in the central Kalimantan Ex-Mega Rice Project area

95. Constraints and options to enhancing production of high quality feeds in dairy production in Kenya, Uganda and Rwanda

2010

96. Agroforestry education in the Philippines: status report from the Southeast Asian Network for Agroforestry Education (SEANAFE)

97. Economic viability of Jatropha curcas L. plantations in Northern Tanzania- assessing farmers' prospects via cost-benefit analysis.

98. Hot spot of emission and confusion: land tenure insecurity, contested policies and competing claims in the central Kalimantan Ex-Mega Rice Project area

99. Agroforestry competences and human resources needs in the Philippines

100. CES/COS/CIS paradigms for compensation and rewards to enhance environmental Services

101. Case study approach to region-wide curriculum and teaching materials development in agroforestry education in Southeast Asia

102. Stewardship agreement to reduce emissions from deforestation and degradation (REDD): Lubuk Beringin's Hutan Desa as the first village forest in Indonesia

103. Landscape dynamics over time and space from ecological perspective

104. Komoditisasi atau koinvestasi jasa lingkungan: skema imbal jasa lingkungan program peduli sungai di DAS Way Besai, Lampung, Indonesia

105. Improving smallholders' rubber quality in Lubuk Beringin, Bungo district, Jambi province, Indonesia: an initial analysis of the financial and social benefits

106. Rapid Carbon Stock Appraisal (RACSA) in Kalahan, Nueva Vizcaya, Philippines

107. Tree domestication by ICRAF and partners in the Peruvian Amazon: lessons learned and future prospects in the domain of the Amazon Initiative eco-regional program

108. Memorias del Taller Nacional: "Iniciativas para Reducir la Deforestación en la region Andino Amazónica", 09 de Abril del 2010. Proyecto REALU Peru

109. Percepciones sobre la Equidad y Eficiencia en la cadena de valor de REDD en Perú -Reporte de Talleres en Ucayali, San Martín y Loreto, 2009. Proyecto REALU-Perú.

110. Reducción de emisiones de todos los Usos del Suelo. Reporte del Proyecto REALU Perú Fase 1

111. Programa Alternativas a la Tumba-y-Quema (ASB) en el Perú. Informe Resumen y Síntesis de la Fase II. 2da. versión revisada

112. Estudio de las cadenas de abastecimiento de germoplasma forestal en la amazonía Boliviana 
113. Biodiesel in the Amazon

114. Estudio de mercado de semillas forestales en la amazonía Colombiana

115. Estudio de las cadenas de abastecimiento de germoplasma forestal en Ecuador http://dx.doi.org10.5716/WP10340.PDF

116. How can systems thinking, social capital and social network analysis help programs achieve impact at scale?

117. Energy policies, forests and local communities in the Ucayali Region, Peruvian Amazon

118. NTFPs as a Source of Livelihood Diversification for Local Communities in the Batang Toru Orangutan Conservation Program

119. Studi Biodiversitas: Apakah agroforestry mampu mengkonservasi keanekaragaman hayati di DAS Konto?

120. Estimasi Karbon Tersimpan di Lahan-lahan Pertanian di DAS Konto, Jawa Timur

121. Implementasi Kaji Cepat Hidrologi (RHA) di Hulu DAS Brantas, Jawa Timur. http://dx.doi.org/10.5716/WP10338.PDF

122. Kaji Cepat Hidrologi di Daerah Aliran Sungai Krueng Peusangan, NAD,Sumatra http://dx.doi.org/10.5716/WP10337.PDF

123. A Study of Rapid Hydrological Appraisal in the Krueng Peusangan Watershed, NAD, Sumatra. http://dx.doi.org/10.5716/WP10339.PDF

\section{1}

124. An Assessment of farm timber value chains in Mt Kenya area, Kenya

125. A Comparative financial analysis of current land use systems and implications for the adoption of improved agroforestry in the East Usambaras, Tanzania

126. Agricultural monitoring and evaluation systems

127. Challenges and opportunities for collaborative landscape governance in the East Usambara Mountains, Tanzania

128. Transforming Knowledge to Enhance Integrated Natural Resource Management Research, Development and Advocacy in the Highlands of Eastern Africa http://dx.doi.org/10.5716/WP11084.PDF

129. Carbon-forestry projects in the Philippines: potential and challenges The Mt Kitanglad Range forestcarbon development http://dx.doi.org10.5716/WP11054.PDF

130. Carbon forestry projects in the Philippines: potential and challenges. The Arakan Forest Corridor forest-carbon project. http://dx.doi.org10.5716/WP11055.PDF

131. Carbon-forestry projects in the Philippines: potential and challenges. The Laguna Lake Development Authority's forest-carbon development project. http://dx.doi.org/10.5716/WP11056.PDF

132. Carbon-forestry projects in the Philippines: potential and challenges. The Quirino forest-carbon development project in Sierra Madre Biodiversity Corridor http://dx.doi.org10.5716/WP11057.PDF

133. Carbon-forestry projects in the Philippines: potential and challenges. The Ikalahan Ancestral Domain forest-carbon development http://dx.doi.org10.5716/WP11058.PDF

134. The Importance of Local Traditional Institutions in the Management of Natural Resources in the Highlands of Eastern Africa. http://dx.doi.org/10.5716/WP11085.PDF

135. Socio-economic assessment of irrigation pilot projects in Rwanda. http://dx.doi.org/10.5716/WP11086.PDF

136. Performance of three rambutan varieties (Nephelium lappaceum L.) on various nursery media. http://dx.doi.org/10.5716/WP11232.PDF 
137. Climate change adaptation and social protection in agroforestry systems: enhancing adaptive capacity and minimizing risk of drought in Zambia and Honduras http://dx.doi.org/10.5716/WP11269.PDF

138. Does value chain development contribute to rural poverty reduction? Evidence of asset building by smallholder coffee producers in Nicaragua http://dx.doi.org/10.5716/WP11271.PDF

139. Potential for biofuel feedstock in Kenya. http://dx.doi.org/10.5716/WP11272.PDF

140. Impact of fertilizer trees on maize production and food security in six districts of Malawi. http://dx.doi.org/10.5716/WP11281.PDF

\section{2}

141. Fortalecimiento de capacidades para la gestión del Santuario Nacional Pampa Hermosa:

Construyendo las bases para un manejo adaptativo para el desarrollo local. Memorias del Proyecto. http://dx.doi.org/10.5716/WP12005.PDF

142. Understanding rural institutional strengthening: A cross-level policy and institutional framework for sustainable development in Kenya http://dx.doi.org/10.5716/WP12012.PDF

143. Climate change vulnerability of agroforestry http://dx.doi.org/10.5716/WP16722.PDF

144. Rapid assesment of the inner Niger delta of Mali http://dx.doi.org/10.5716/WP12021.PDF

145. Designing an incentive program to reduce on-farm deforestationin the East Usambara Mountains, Tanzania http://dx.doi.org/10.5716/WP12048.PDF

146. Extent of adoption of conservation agriculture and agroforestry in Africa: the case of Tanzania, Kenya, Ghana, and Zambia http://dx.doi.org/10.5716/WP12049.PDF

147. Policy incentives for scaling up conservation agriculture with trees in Africa: the case of Tanzania, Kenya, Ghana and Zambia http://dx.doi.org/10.5716/WP12050.PDF

148. Commoditized or co-invested environmental services? Rewards for environmental services scheme: River Care program Way Besai watershed, Lampung, Indonesia. http://dx.doi.org/10.5716/WP12051.PDF

149. Assessment of the headwaters of the Blue Nile in Ethiopia. http://dx.doi.org/10.5716/WP12160.PDF

150. Assessment of the uThukela Watershed, Kwazaulu. http://dx.doi.org/10.5716/WP12161.PDF

151. Assessment of the Oum Zessar Watershed of Tunisia. http://dx.doi.org/10.5716/WP12162.PDF

152. Assessment of the Ruwenzori Mountains in Uganda. http://dx.doi.org/10.5716/WP12163.PDF

153. History of agroforestry research and development in Viet Nam. Analysis of research opportunities and gaps. http://dx.doi.org/10.5716/WP12052.PDF

154. REDD+ in Indonesia: a Historical Perspective. http://dx.doi.org/10.5716/WP12053.PDF

155. Agroforestry and Forestry in Sulawesi series: Livelihood strategies and land use system dynamics in South Sulawesi http://dx.doi.org/10.5716/WP12054.PDF

156. Agroforestry and Forestry in Sulawesi series: Livelihood strategies and land use system dynamics in Southeast Sulawesi. http://dx.doi.org/10.5716/WP12055.PDF

157. Agroforestry and Forestry in Sulawesi series: Profitability and land-use systems in South and Southeast Sulawesi. http://dx.doi.org/10.5716/WP12056.PDF

158. Agroforestry and Forestry in Sulawesi series: Gender, livelihoods and land in South and Southeast Sulawesi http://dx.doi.org/10.5716/WP12057.PDF

159. Agroforestry and Forestry in Sulawesi series: Agroforestry extension needs at the community level in AgFor project sites in South and Southeast Sulawesi, Indonesia. http://dx.doi.org/10.5716/WP12058.PDF

160. Agroforestry and Forestry in Sulawesi series: Rapid market appraisal of agricultural, plantation and forestry commodities in South and Southeast Sulawesi. http://dx.doi.org/10.5716/WP12059.PDF 


\section{3}

161. Diagnosis of farming systems in the Agroforestry for Livelihoods of Smallholder farmers in Northwestern Viet Nam project http://dx.doi.org/10.5716/WP13033.PDF

162. Ecosystem vulnerability to climate change: a literature review. http://dx.doi.org/10.5716/WP13034.PDF

163. Local capacity for implementing payments for environmental services schemes: lessons from the RUPES project in northeastern Viet Nam http://dx.doi.org/10.5716/WP13046.PDF

164. Seri Agroforestri dan Kehutanan di Sulawesi: Agroforestry dan Kehutanan di Sulawesi: Strategi mata pencaharian dan dinamika sistem penggunaan lahan di Sulawesi Selatan http://dx.doi.org/10.5716/WP13040.PDF

165. Seri Agroforestri dan Kehutanan di Sulawesi: Mata pencaharian dan dinamika sistem penggunaan lahan di Sulawesi Tenggara http://dx.doi.org/10.5716/WP13041.PDF

166. Seri Agroforestri dan Kehutanan di Sulawesi: Profitabilitas sistem penggunaan lahan di Sulawesi Selatan dan Sulawesi Tenggara http://dx.doi.org/10.5716/WP13042.PDF

167. Seri Agroforestri dan Kehutanan di Sulawesi: Gender, mata pencarian dan lahan di Sulawesi Selatan dan Sulawesi Tenggara http://dx.doi.org/10.5716/WP13043.PDF

168. Seri Agroforestri dan Kehutanan di Sulawesi: Kebutuhan penyuluhan agroforestri pada tingkat masyarakat di lokasi proyek AgFor di Sulawesi Selatan dan Tenggara, Indonesia. http://dx.doi.org/10.5716/WP13044.PDF

169. Seri Agroforestri dan Kehutanan di Sulawesi: Laporan hasil penilaian cepat untuk komoditas pertanian, perkebunan dan kehutanan di Sulawesi Selatan dan Tenggara http://dx.doi.org/10.5716/WP13045.PDF

170. Agroforestry, food and nutritional security http://dx.doi.org/10.5716/WP13054.PDF

171. Stakeholder Preferences over Rewards for Ecosystem Services: Implications for a REDD+ Benefit Distribution System in Viet Nam http://dx.doi.org/10.5716/WP13057.PDF

172. Payments for ecosystem services schemes: project-level insights on benefits for ecosystems and the rural poor http://dx.doi.org/10.5716/WP13001.PDF

173. Good practices for smallholder teak plantations: keys to success http://dx.doi.org/10.5716/WP13246.PDF

174. Market analysis of selected agroforestry products in the Vision for Change Project intervention Zone, Côte d'Ivoire http://dx.doi.org/10.5716/WP13249.PDF

175. Rattan futures in Katingan: why do smallholders abandon or keep their gardens in Indonesia's 'rattan district'? http://dx.doi.org/10.5716/WP13251.PDF

176. Management along a gradient: the case of Southeast Sulawesi's cacao production landscapes http://dx.doi.org/10.5716/WP13265.PDF

\section{4}

177. Are trees buffering ecosystems and livelihoods in agricultural landscapes of the Lower Mekong Basin? Consequences for climate-change adaptation. http://dx.doi.org/10.5716/WP14047.PDF

178. Agroforestry, livestock, fodder production and climate change adaptation and mitigation in East Africa: issues and options. http://dx.doi.org/10.5716/WP14050.PDF

179. Trees on farms: an update and reanalysis of agroforestry's global extent and socio-ecological characteristics. http://dx.doi.org/10.5716/WP14064.PDF

180. Beyond reforestation: an assessment of Vietnam's REDD+ readiness. http://dx.doi.org/10.5716/WP14097.PDF 
181. Farmer-to-farmer extension in Kenya: the perspectives of organizations using the approach. http://dx.doi.org/10.5716/WP14380.PDF

182. Farmer-to-farmer extension in Cameroon: a survey of extension organizations. http://dx.doi.org/10.5716/WP14383.PDF

183. Farmer-to-farmer extension approach in Malawi: a survey of organizations: a survey of organizations http://dx.doi.org/10.5716/WP14391.PDF

184. Seri Agroforestri dan Kehutanan di Sulawesi: Kuantifikasi jasa lingkungan air dan karbon pola agroforestri pada hutan rakyat di wilayah sungai Jeneberang

185. Options for Climate-Smart Agriculture at Kaptumo Site in Kenyahttp://dx.doi.org/10.5716/WP14394.PDF

\section{5}

186. Agroforestry for Landscape Restoration and Livelihood Development in Central Asia http://dx.doi.org/10.5716/WP14143.PDF

187. "Projected Climate Change and Impact on Bioclimatic Conditions in the Central and South-Central Asia Region" http://dx.doi.org/10.5716/WP14144.PDF

188. Land Cover Changes, Forest Loss and Degradation in Kutai Barat, Indonesia. http://dx.doi.org/10.5716/WP14145.PDF

189. The Farmer-to-Farmer Extension Approach in Malawi: A Survey of Lead Farmers. http://dx.doi.org/10.5716/WP14152.PDF

190. Evaluating indicators of land degradation and targeting agroforestry interventions in smallholder farming systems in Ethiopia. http://dx.doi.org/10.5716/WP14252.PDF

191. Land health surveillance for identifying land constraints and targeting land management options in smallholder farming systems in Western Cameroon

192. Land health surveillance in four agroecologies in Malawi

193. Cocoa Land Health Surveillance: an evidence-based approach to sustainable management of cocoa landscapes in the Nawa region, South-West Côte d'Ivoire http://dx.doi.org/10.5716/WP14255.PDF

194. Situational analysis report: Xishuangbanna autonomous Dai Prefecture, Yunnan Province, China. http://dx.doi.org/10.5716/WP14255.PDF

195. Farmer-to-farmer extension: a survey of lead farmers in Cameroon. http://dx.doi.org/10.5716/WP15009.PDF

196. From transition fuel to viable energy source Improving sustainability in the sub-Saharan charcoal sector http://dx.doi.org/10.5716/WP15011.PDF

197. Mobilizing Hybrid Knowledge for More Effective Water Governance in the Asian Highlands http://dx.doi.org/10.5716/WP15012.PDF

198. Water Governance in the Asian Highlands http://dx.doi.org/10.5716/WP15013.PDF

199. Assessing the Effectiveness of the Volunteer Farmer Trainer Approach in Dissemination of Livestock Feed Technologies in Kenya vis-à-vis other Information Sources http://dx.doi.org/10.5716/WP15022.PDF

200. The rooted pedon in a dynamic multifunctional landscape: Soil science at the World Agroforestry Centre http://dx.doi.org/10.5716/WP15023.PDF

201. Characterising agro-ecological zones with local knowledge. Case study: Huong Khe district, Ha Tinh, Viet Nam http://dx.doi.org/10.5716/WP15050.PDF

202. Looking back to look ahead: Insight into the effectiveness and efficiency of selected advisory approaches in the dissemination of agricultural technologies indicative of Conservation Agriculture with Trees in Machakos County, Kenya. http://dx.doi.org/10.5716/WP15065.PDF

203. Pro-poor Biocarbon Projects in Eastern Africa Economic and Institutional Lessons. http://dx.doi.org/10.5716/WP15022.PDF 
204. Projected climate change impacts on climatic suitability and geographical distribution of banana and coffee plantations in Nepal. http://dx.doi.org/10.5716/WP15294.PDF

205. Agroforestry and Forestry in Sulawesi series: Smallholders' coffee production and marketing in Indonesia. A case study of two villages in South Sulawesi Province. http://dx.doi.org/10.5716/WP15690.PDF

206. Mobile phone ownership and use of short message service by farmer trainers: a case study of Olkalou and Kaptumo in Kenya http://dx.doi.org/10.5716/WP15691.PDF

207. Associating multivariate climatic descriptors with cereal yields: a case study of Southern Burkina Faso http://dx.doi.org/10.5716/WP15273.PDF

208. Preferences and adoption of livestock feed practices among farmers in dairy management groups in Kenya http://dx.doi.org/10.5716/WP15675.PDF

209. Scaling up climate-smart agriculture: lessons learned from South Asia and pathways for success http://dx.doi.org/10.5716/WP15720.PDF

210. Agroforestry and Forestry in Sulawesi series: Local perceptions of forest ecosystem services and collaborative formulation of reward mechanisms in South and Southeast Sulawesi http://dx.doi.org/10.5716/WP15721.PDF

211. Potential and challenges in implementing the co-investment of ecosystem services scheme in Buol District, Indonesia. http://dx.doi.org/10.5716/WP15722.PDF

212. Tree diversity and its utilization by the local community in Buol District, Indonesia http://dx.doi.org/10.5716/WP15723.PDF

213 Vulnerability of smallholder farmers and their preferences on farming practices in Buol District, Indonesia http://dx.doi.org/10.5716/WP15724.PDF

214. Dynamics of Land Use/Cover Change and Carbon Emission in Buol District, Indonesia http://dx.doi.org/10.5716/WP15725.PDF

215. Gender perspective in smallholder farming practices in Lantapan, Phillippines. http://dx.doi.org/10.5716/WP15726.PDF

216. Vulnerability of smallholder farmers in Lantapan, Bukidnon. http://dx.doi.org/10.5716/WP15727.PDF

217. Vulnerability and adaptive capacity of smallholder farmers in Ho Ho Sub-watershed, Ha Tinh Province, Vietnam http://dx.doi.org/10.5716/WP15728.PDF

218. Local Knowledge on the role of trees to enhance livelihoods and ecosystem services in northern central Vietnam http://dx.doi.org/10.5716/WP15729.PDF

219. Land-use/cover change in Ho Ho Sub-watershed, Ha Tinh Province, Vietnam. http://dx.doi.org/10.5716/WP15730.PDF

2016

220. Agroforestry and Forestry in Sulawesi series: Evaluation of the Agroforestry Farmer Field Schools on agroforestry management in South and Southeast Sulawesi, Indonesia.

http://dx.doi.org/10.5716/WP16002.PDF 


The World Agroforestry Centre is an autonomous, non-profit research organization whose vision is a rural transformation in the developing world as smallholder households increase their use of trees in agricultural landscapes to improve food security, nutrition, income, health, shelter, social cohesion, energy resources and environmental sustainability. The Centre generates science-based knowledge about the diverse roles that trees play in agricultural landscapes, and uses its research to advance policies and practices, and their implementation that benefit the poor and the environment. It aims to ensure that all this is achieved by enhancing the quality of its science work, increasing operational efficiency, building and maintaining strong partnerships, accelerating the use and impact of its research, and promoting greater cohesion, interdependence and alignment within the organization.

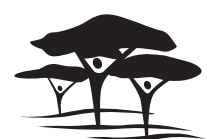

United Nations Avenue, Gigiri • PO Box 30677 • Nairobi, $00100 \cdot$ Kenya Telephone: +254 207224000 or via USA +1 6508336645 Fax: +254207224001 or via USA +1 6508336646

Email: worldagroforestry@cgiar.org•www.worldagroforestry.org

Southeast Asia Regional Program • Sindang Barang • Bogor 16680

PO Box $161 \cdot$ Bogor $16001 \cdot$ Indonesia

Telephone: +62 2518625415 • Fax: +62 2518625416

- Email: icraf-indonesia@cgiar.org

www.worldagroforestry.org/regions/southeast_asia

blog.worldagroforestry.org 